\title{
Floodplains: the forgotten and abused component of the fluvial system
}

\author{
George Heritage ${ }^{1}$, Neil S. Entwistle ${ }^{2, a}$ and Seb Bentley ${ }^{3}$ \\ ${ }^{1}$ AECOM, Exchange Court, 1 Dale Street, Liverpool, L2 2ET, UK \\ ${ }^{2}$ University of Salford, School of Environment and Life Sciences, Salford M5 4WT, UK \\ ${ }^{3}$ AECOM, Victoria Square House, Victoria Square, Birmingham B2 4AJ, UK
}

\begin{abstract}
River restoration is strongly focussed on in-channel initiatives driven by fisheries interests and a continued desire for river stability. This contrasts greatly with the inherently mobile nature of watercourses. What is often overlooked is the fact that many rivers have developed floodplain units that would naturally operate as integrated functional systems, moderating the effects of extreme floods by distributing flow energy and sediment transport capacity through out of bank flooding. Floodplain utilisation for farming activities and landowner intransigence when it comes to acknowledging that the floodplain is part of the river system, has resulted in floodplains being the most degraded fluvial morphologic unit, both in terms of loss of form and function and sheer levels of spatial impact. The degradation has been facilitated by the failure of regulatory mechanisms to adequately acknowledge floodplain form and function. This is testament to the 'inward looking' thinking behind national assessment strategies. This paper reviews the state of floodplain systems drawing on quantitative data from England and Wales to argue for greater consideration of the floodplain in relation to river management. The database is poor and must be improved, however it does reveal significant loss of watercourse-floodplain connectivity linked to direct flood alleviation measures and also to altered flood frequency as a result of river downcutting following river engineering. These latter effects have persisted along many watercourses despite the historic nature of the engineering interventions and will continue to exacerbate the risk of flooding to downstream communities. We also present several examples of the local and wider values of reinstating floodplain form and function, demonstrating major ecological gains, improvement to downstream flood reduction, elevation of water quality status and reductions in overall fine sediment loss from farmland. A re-think is required regarding our approach to managing floodplains and funding floodplain restoration, arguing for greater recognition of the natural role of the floodplain as a resource for upstream flood management and as an agent for overall biotic improvement in line with restoration objectives.
\end{abstract}

\section{Introduction}

Natural floodplains have been shown to be among the most biologically productive and diverse ecosystems on earth [1]. This is in a large part due to their dynamic nature forming the transitional ecotone between aquatic and terrestrial environments. Natural fluvial dynamics result in flood-controlled disturbances, encouraging geomorphic processes and successional patterns (e.g. [2, 3]. As a result, floodplains in their natural state exhibit complex dynamic spatial mosaics controlled by the surface and subsurface hydrological regime [4]. These features also reflect past and present geomorphological activity associated with the fluvial system [5] with features developing ecologically as connectivity with the main river alters over time.

Mitsch \& Gosselink [6] estimated that globally floodplains cover between $0.8 \times 106 \mathrm{~km}^{2}$ to $2 \times 106 \mathrm{~km}^{2}$, approximately $1.4 \%$ of the land surface, however they contribute around $25 \%$ of all terrestrial ecosystem services [1]. Recent figures on floodplain state are not known to the authors, however the situation is unlikely to

\footnotetext{
${ }^{\mathrm{a}}$ Neil S. Entwistle: n.entwistle@salford.ac.uk
}

have improved on the status levels reported at the turn of the century when it was estimated that some $80 \%-90 \%$ of Europe's river floodplains are now cultivated intensively compared to figures of $46 \%$ for North America (excluding northern Canada and Alaska) and $11 \%$ for African Rivers [1]. As such floodplain condition and functionality has been reported as being in a critical situation across Europe [7, 8].

Longitudinal and lateral fragmentation of large river systems, linked principally to human activities has led to severe and widespread floodplain degradation and this is fundamentally threatening the integrity of running water ecosystems $[9,10]$. This degradation is closely linked to the rapid decline in freshwater biodiversity linked principally to habitat alteration through altered land use and flow and flood control and also to invasive species and pollution. Tockner [1] provides the stark statistic that in Europe and North America, up to $90 \%$ of floodplains are already 'cultivated' and therefore functionally extinct.

In England and Wales watercourse and to a lesser degree floodplain alteration and degradation has been quantified as part of the European Water Framework 
Directive (WFD) with water bodies classified based on their degree of alteration as artificial, heavily modified and near natural (non designated). Each of these river types has been reviewed for floodplain loss due to formal defences protecting areas to the 100 year return period flood level (Table 1). It is interesting to note that the percentage impact is greatest for artificial watercourses followed by heavily modified systems with non designated (near natural) systems being the least impacted.

The figures suggest a rather lower degree of impact than that reported more generally with regard to floodplain degradation across Europe. It is suggested that this is not the case in reality in England and Wales with informal defences and historic and current river engineering (most notably dredging) acting to disconnect watercourses from their floodplains across a much greater area, additionally standards of protection vary, creating a variable floodplain wetting frequency. Across England some 44 rivers are designated as Sites of Special Scientific Interest (SSSI) for their ecological integrity.

\begin{tabular}{|l|l|r|r|}
\hline \multirow{2}{*}{$\begin{array}{l}\text { Total } \\
\text { floodplain } \\
\text { area }\left(\mathrm{km}^{2}\right)\end{array}$} & River type & England & Wales \\
\cline { 2 - 4 } & $\begin{array}{l}\text { Heavily Modified } \\
\text { Water Body }\end{array}$ & 568.1 & \\
\cline { 2 - 4 } & Non Designated & 1451.9 & 450.2 \\
\cline { 2 - 4 } & All & 5458.0 & 667.8 \\
\hline $\begin{array}{l}\text { Defended } \\
\text { floodplain } \\
\text { area (100 } \\
\text { year RP } \\
\text { flow) } \\
\left.\text { (km }{ }^{2}\right)\end{array}$ & Artificial Water Body & 363.3 & \\
\cline { 2 - 4 } & Heavily Modified & 338.4 & 55.0 \\
\cline { 2 - 4 } & Water Body & 78.1 & 5.8 \\
\cline { 2 - 4 } $\begin{array}{l}\text { Percentage } \\
\text { impact }\end{array}$ & All Designated & 64.0 & 60.8 \\
\cline { 2 - 4 } & Artificial Water Body & 9.8 & 25.3 \\
\cline { 2 - 4 } & Weavily Modified & 5.4 & 1.3 \\
\cline { 2 - 4 } & Non Designated & 14.3 & 9.1 \\
\cline { 2 - 4 } & All & 779.7 & \\
\hline
\end{tabular}

Table 1. Impact of formal flood defences on Floodplain connectivity in England and Wales.

This paper reviews the extent of disconnection on eight of these whole river sites in England (Table 2) highlighting the spatial disruption to flood driven geomorphic processes and natural floodplain functioning and contrasting the nature and dynamics of functional verses non-functional reaches along these watercourses. It is immediately interesting to note how the environmental designations for these SSSI rivers is strongly centred on the watercourse with only occasional mention of notable floodplain habitats, probably reflecting the degraded nature of the valley bottom, with boundaries of these SSSI Units are often drawn along the bank edges, ignoring the floodplain entirely. Observation of land use patterns on the rivers confirms this with the floodplains on all of the watercourses heavily modified by arable and pastoral land use with only isolated areas of woodland, marsh, fen and swamp habitat and very little functional palaeo-habitat associated with active river dynamics.

\begin{tabular}{|c|c|c|}
\hline River & Typical land use & Designations \\
\hline Wharfe & $\begin{array}{l}\text { Pasture, occasional } \\
\text { low intensity usage, } \\
\text { small settlements }\end{array}$ & $\begin{array}{l}\text { base-rich, } \\
\text { mesotrophic river, } \\
\text { fen, marsh and } \\
\text { swamp, Lowland } \\
\text { neutral grassland }\end{array}$ \\
\hline Eye & $\begin{array}{l}\text { Mostly pasture, some } \\
\text { arable, small towns }\end{array}$ & $\begin{array}{l}\text { low-flowing, } \\
\text { naturally eutrophic } \\
\text { lowland rivers, } \\
\text { dominated by clays }\end{array}$ \\
\hline Teme & $\begin{array}{l}\text { Arable, pasture, mixed } \\
\text { woodland, occasional } \\
\text { low intensity usage, } \\
\text { small towns }\end{array}$ & $\begin{array}{l}\text { base-rich, } \\
\text { mesotrophic river }\end{array}$ \\
\hline Frome & $\begin{array}{l}\text { Arable, some pasture, } \\
\text { mixed woodland, } \\
\text { variable sized } \\
\text { settlements }\end{array}$ & $\begin{array}{l}\text { naturally eutrophic } \\
\text { lowland river, } \\
\text { broadleaved, mixed } \\
\text { and yew woodland - } \\
\text { lowland, dwarf shrub } \\
\text { heath - lowland, fen, } \\
\text { marsh and swamp, } \\
\text { neutral grassland - } \\
\text { lowland }\end{array}$ \\
\hline Mease & $\begin{array}{l}\text { Arable, some pasture, } \\
\text { wetland and ponds }\end{array}$ & $\begin{array}{l}\text { naturally eutrophic } \\
\text { lowland river }\end{array}$ \\
\hline Ribble & $\begin{array}{l}\text { Pasture, occasional } \\
\text { arable, variable sized } \\
\text { settlements }\end{array}$ & $\begin{array}{l}\text { base-rich, } \\
\text { mesotrophic river }\end{array}$ \\
\hline Eden & $\begin{array}{l}\text { Pasture, occasional } \\
\text { arable, variable sized } \\
\text { settlements }\end{array}$ & $\begin{array}{l}\text { base-rich, } \\
\text { mesotrophic river, } \\
\text { mixed woodland }\end{array}$ \\
\hline Wensum & $\begin{array}{l}\text { Arable and pasture, } \\
\text { wetland, small to } \\
\text { medium sized } \\
\text { settlements }\end{array}$ & $\begin{array}{l}\text { naturally eutrophic } \\
\text { lowland rivers, fen, } \\
\text { marsh and swamp }\end{array}$ \\
\hline
\end{tabular}

Table 2. Character and designations for the SSSI study rivers.

\section{Study Sites}

A selection of eight whole river Sites of Special Scientific Interest (SSSI) were analysed to assess river and floodplain connectivity and embankment presence (Figure 1):

- The River Wharfe SSSI from Beckermonds in the Yorkshire Dales National Park to Kirby Wharfe

- The River Ribble SSSI from High Birkwith in the Yorkshire Dales National Park to Preston

- The River Teme SSSI from Felindre to Powick at the confluence with the River Severn

- The River Eye SSSI (including River Wreake) from Whissendine to the confluence with the River Soar at Rothley

- The Dorset River Frome SSSI from Chalmington to the tidal limit at Wareham

- The River Eden SSSI from Kirkby Stephen to the tidal limit at Beaumont 
- The River Wensum SSSI from Tatterford to the tidal limit at Norwich

- The River Mease SSSI from Shackerstone to the confluence with the River Trent

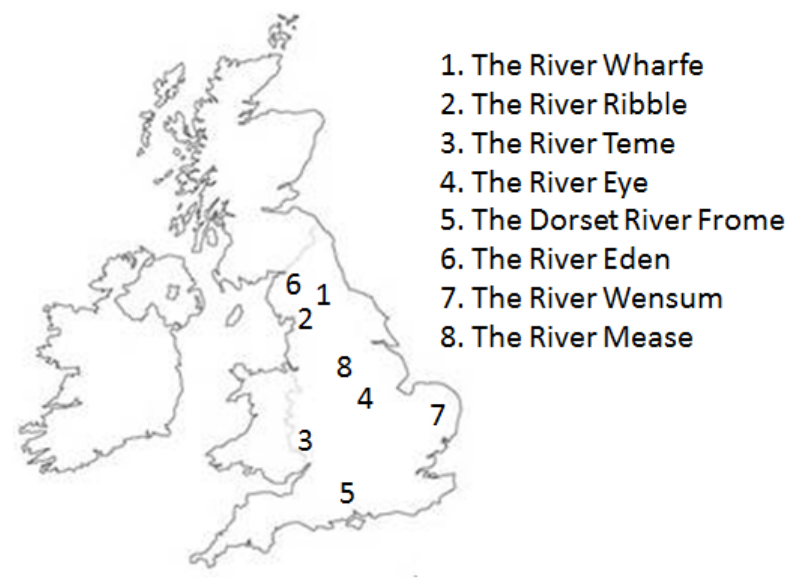

Figure 1. Location of the whole river Sites of Special Scientific Interest analysed.

\section{Method}

Connectivity and the presence and height of embankments, either formal or informal, has been assessed using open source LIDAR available from the English Environment Agency who retain copyright and/or database right to the data. The data is available at $2 \mathrm{~m}$ resolution as a digital surface model and as a filtered digital terrain model version which is able to accurately depict floodplain elevation to within +- $0.15 \mathrm{~m}$ [11]. Points were queried at regular intervals along each watercourse where floodplain was present in order to identify a representative elevation of the channel bed. This ignored erroneous data points created as a result of issues with LIDAR returns across the water surface and likely represents an over estimation of the average bed level due to lack of penetration of the LIDAR pulse through deep water $[12,13]$. The location of formal flood defence embankments were identified using freely available flood defence GIS layers from the Environment Agency (C) Environment Agency copyright and/or database right 2016).

Spot level analysis was undertaken using the LIDAR in ArcGIS along the SSSI river floodplain reaches to record a representative elevation within the river channel (metres Above Ordnance Datum - mAOD), right and left bank natural floodplain elevation (mAOD), informal or formal embankment elevations (mAOD) and the width of the river channel $(\mathrm{m})$ that was cross-referenced with Ordnance Survey Streetview OpenData (Figure 2). Working from upstream to downstream along each river, points were selected at regular intervals and also where there was considered to be a change in floodplain character from the last location and where the presence of an informal or formal embankment was identified. Channel type was also noted at each survey location.

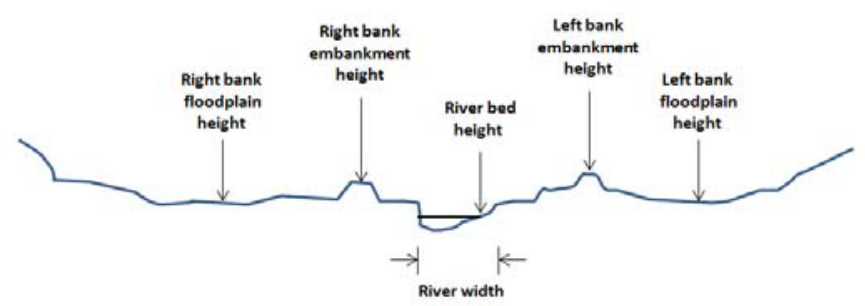

Figure 2. Example cross-section with typical sample point locations indicated (flow is coming out of the page).

This provides a comprehensive dataset to analyse river and floodplain connectivity for these systems through comparison of elevations in the channel and the floodplain, and the influence of embankments through comparison of elevation in the channel and floodplain and elevations of embankments, along these SSSI Rivers that rely on strong connectivity to maintain the characteristic geomorphology and ecology for which they are designated. Rosgen [14] found naturally connected alluvial systems displayed a width depth ration around 12. Regime equations developed on data from stable alluvial channels suggest that channel width and depth may be predicted from bankfull discharge with the multiplier and exponent varying around 3 and $0.4-0.5$ for channel width and 0.25 and 0.3 for depth [15] suggesting a stable width depth ration of between 10 and 12. Connectivity was calculated by subtracting the river elevation from the floodplain and embankment elevations and the value was categorised according to a connectivity index based around the stable dimensions reported above:

$\begin{array}{ll}\text { Disconnected } & W / d<=5 \\ \text { Poorly connected } & W / d>5 \text { and }<=9 \\ \text { Naturally connected } & W / d>9 \text { and }<=12 \\ \text { Strongly connected } & W / d>12\end{array}$

\section{Results}

\subsection{Floodplain connectivity}

A total of 266 sections were analysed across the eight SSSI rivers. Figure 3 illustrates the distribution of connectivity. On average $46 \%$ of the sites were very well connected, $15 \%$ were connected, $29 \%$ were poorly connected and $10 \%$ were disconnected. These results suggest that floodplain function is mixed across all of the rivers with reaches displaying strong connection and others showing a reduced flooding frequency as a result of lower connectivity. Reviewing the data on a river by river basis (Figure 4) suggests that the Wharfe, Ribble, Frome, Eden and Wensum have floodplains that are better connected than the Eye, Teme or Mease with over half of the River Teme and the River Mease being strongly disconnected. In these cases the disconnectivity is likely to be due to bed lowering triggered by dredging or disruption to the sediment supply from upstream. This 
is illustrated very clearly when the spatial connectivity pattern for the River Teme is analysed (Figure 5). The lower reaches are very strongly disconnected (Figure 6a) in contrast to the functional floodplain reaches seen upstream (Figure 6b).

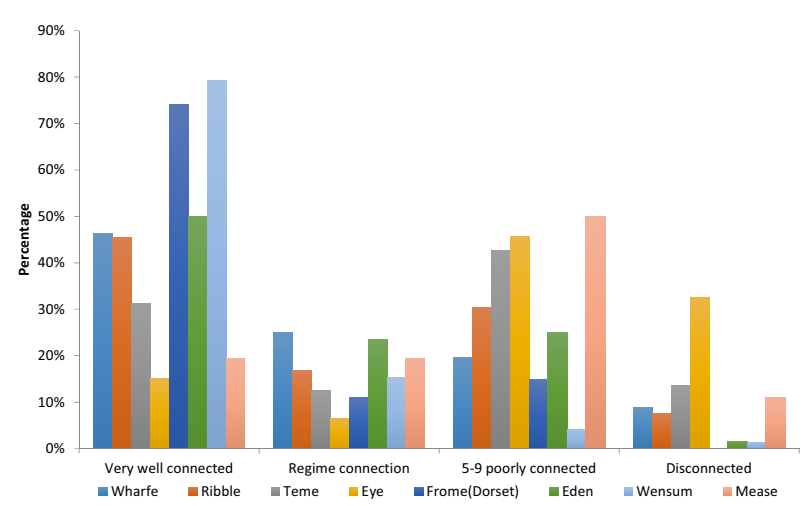

Figure 3. Overview of floodplain connectivity for the 8 SSSI study rivers.

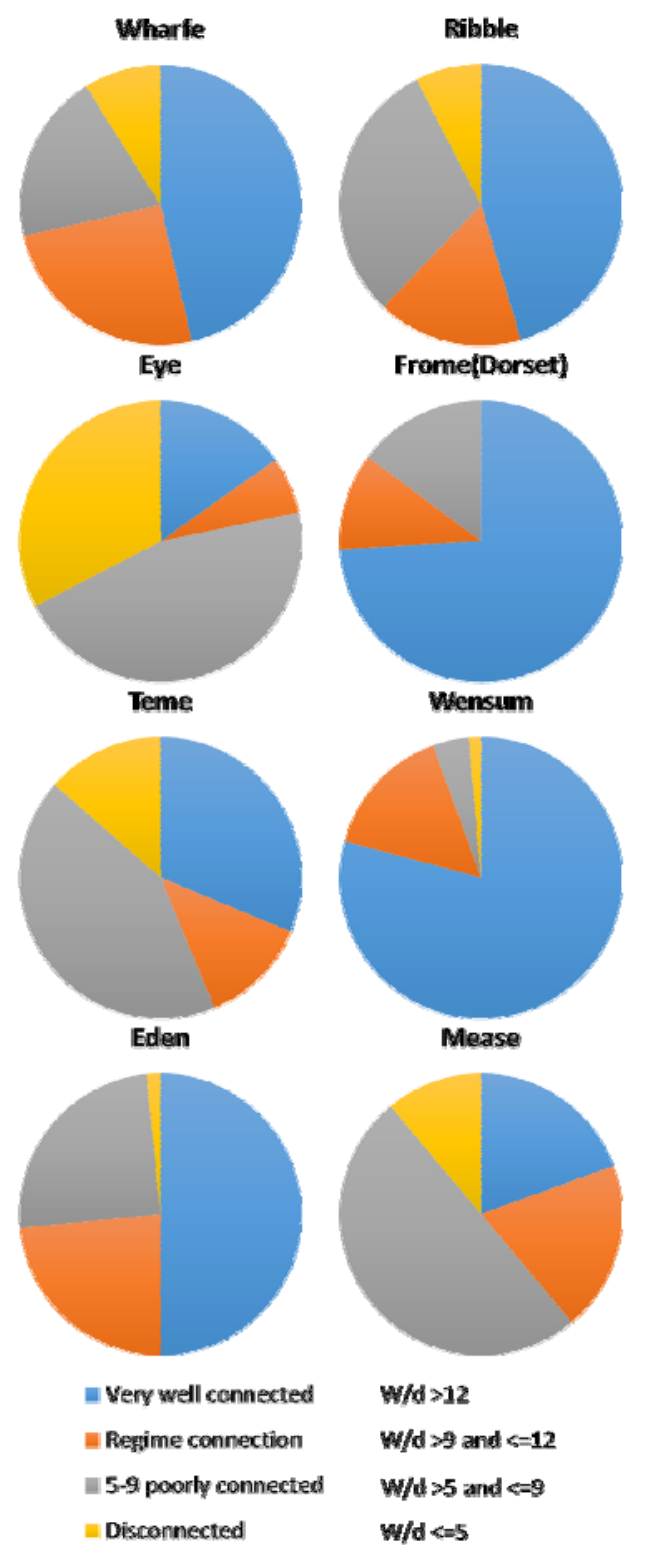

Figure 4. Floodplain connectivity across the SSSI river sample sites.

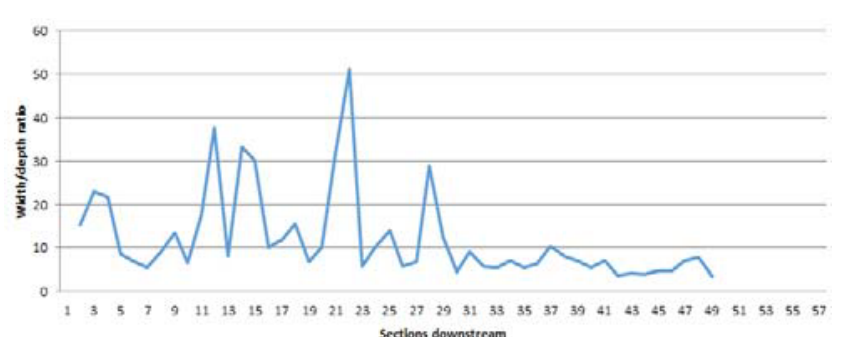

Figure 5. Downstream variation in connectivity along the River Teme SSSI.
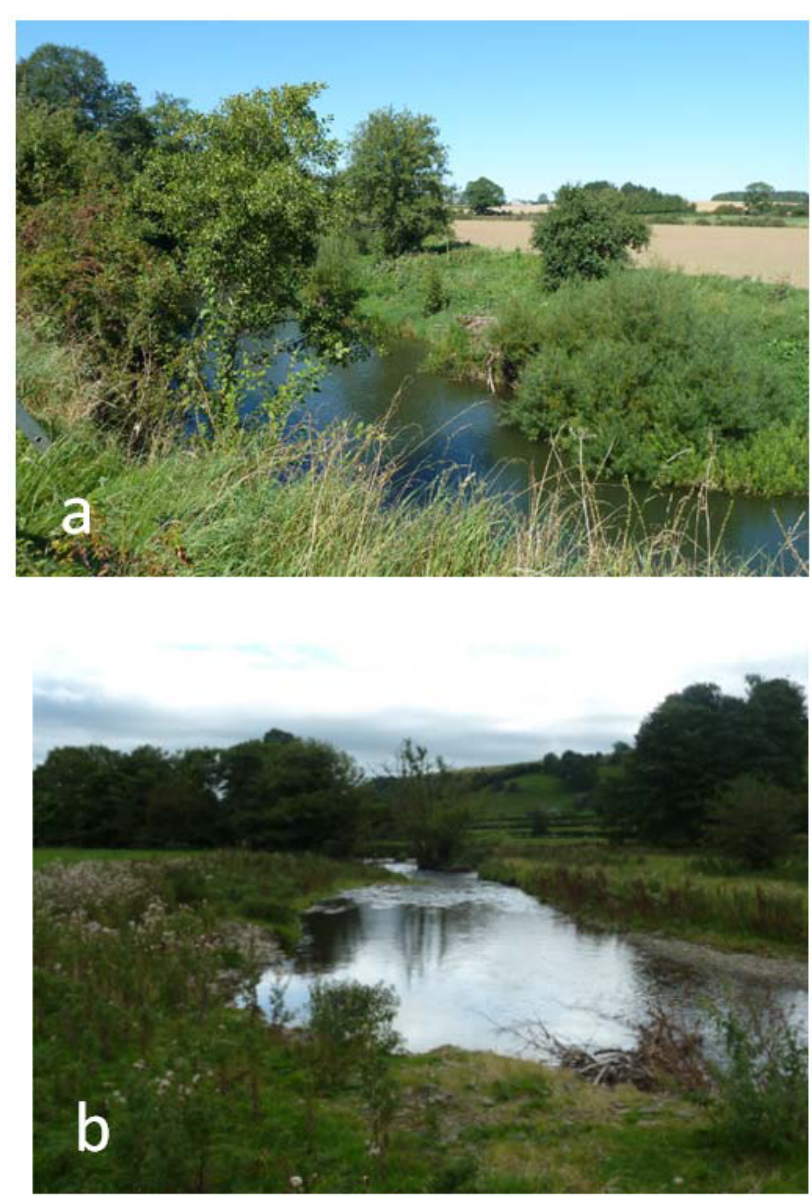

Figure 6. Contrasting floodplain functionality along (a) disconnected and (b) strongly connected reaches of the River Teme.

\subsection{Embankment impact}

Despite the SSSI status of the watercourses assessed many areas of floodplain are influenced by embankments (Figure 7). All of the rivers are impacted to varying levels ranging from $10 \%$ of surveyed sections for the Eye and Mease to just over $40 \%$ for the River Wensum. Interestingly many of these embankments do not form part of the English Environment Agency database as they offer protection below the 100 year return period flow (Table 3). This is not surprising for rural floodplain areas where the level of protection would generally be lower but it does indicate that the percentage of river where the natural flood regime is impacted is far greater than can be 
estimated using the data produced for the Water Framework Directive. In all cases embankments increase disconnectivity locally (see for example Figure 7). Generally $10-15 \%$ of sections have become disconnected due to embankment impact on flooding (Figure 8) with the River Wharfe (figure 9) and the River Ribble particularly impacted having over $40 \%$ of study sections disconnected as a result of embankments.

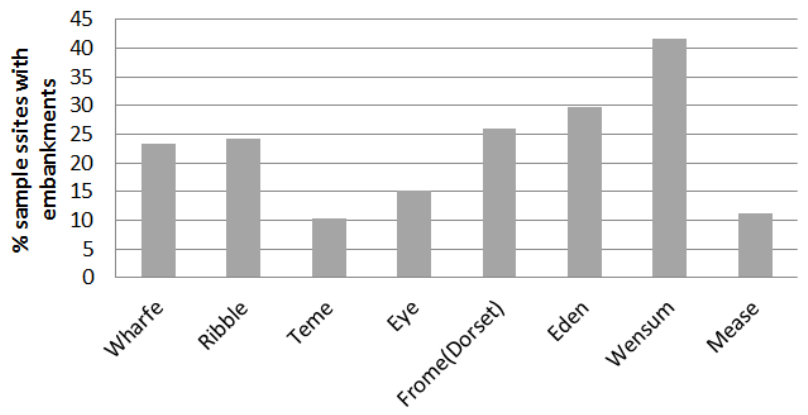

Figure 7. Percentage of SSSI river sample sites impacted by floodplain embankments.

\begin{tabular}{|l|r|r|r|r|}
\hline & \multicolumn{1}{|l|}{ Wharfe } & \multicolumn{1}{|l|}{ Ribble } & \multicolumn{1}{|l|}{ Teme } & \multicolumn{1}{|l|}{ Eye } \\
\hline $\begin{array}{l}\text { Embankments not } \\
\text { recognised }\end{array}$ & 5 & 10 & 9 & 6 \\
\hline $\begin{array}{l}\text { Official } \\
\text { embankments }\end{array}$ & 17 & 1 & 0 & 0 \\
\hline $\begin{array}{l}\text { \% embankments not } \\
\text { officially recognised }\end{array}$ & 22.7 & 90.9 & 100 & 100 \\
\hline $\begin{array}{l}\text { Frome } \\
\text { (Dorset) }\end{array}$ & Eden & Wensum & Mease \\
\hline $\begin{array}{l}\text { Embankments not } \\
\text { recognised }\end{array}$ & 9 & 9 & 19 & 3 \\
\hline $\begin{array}{l}\text { Official } \\
\text { embankments }\end{array}$ & 1 & 5 & 0 & 0 \\
\hline $\begin{array}{l}\text { \% embankments not } \\
\text { officially recognised }\end{array}$ & 90 & 64.3 & 100 & 100 \\
\hline
\end{tabular}

Table 3. Embankments not officially considered in the defences database for England and Wales

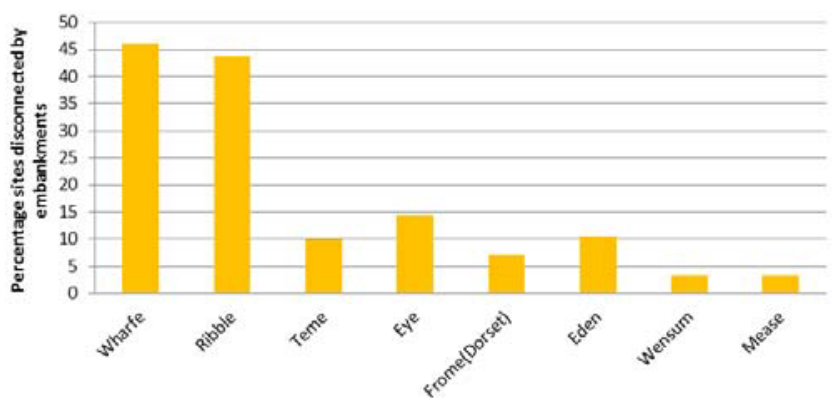

Figure 9. Embankment influence on hydrological connectivity across the 8 SSSI study rivers.

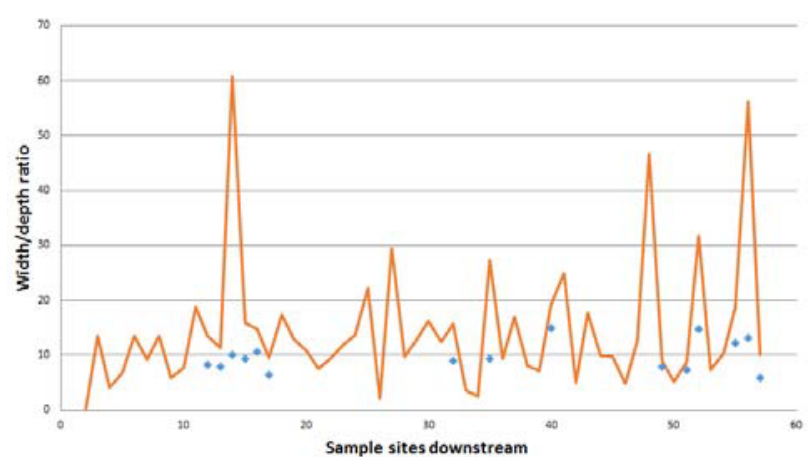

Figure 8. Example impact of embankments on connectivity along the River Wharfe SSSI (orange line = current floodplain connectivity, blue diamond $=$ embankment related connectivity).

\subsection{Connectivity and channel type}

Of note along the SSSI watercourses is the variation in channel type. Much of the studied river lengths were characterised by an inactive sinuous single thread channel type, however, interspersed within this were shorter lengths of either active sinuous single thread or wandering type channels (Figure 10). Inspection of the connectivity index associated with these more dynamic and varied channels on the River Teme (Figure 10) suggests that they are strongly associated with strongly connected river reaches.

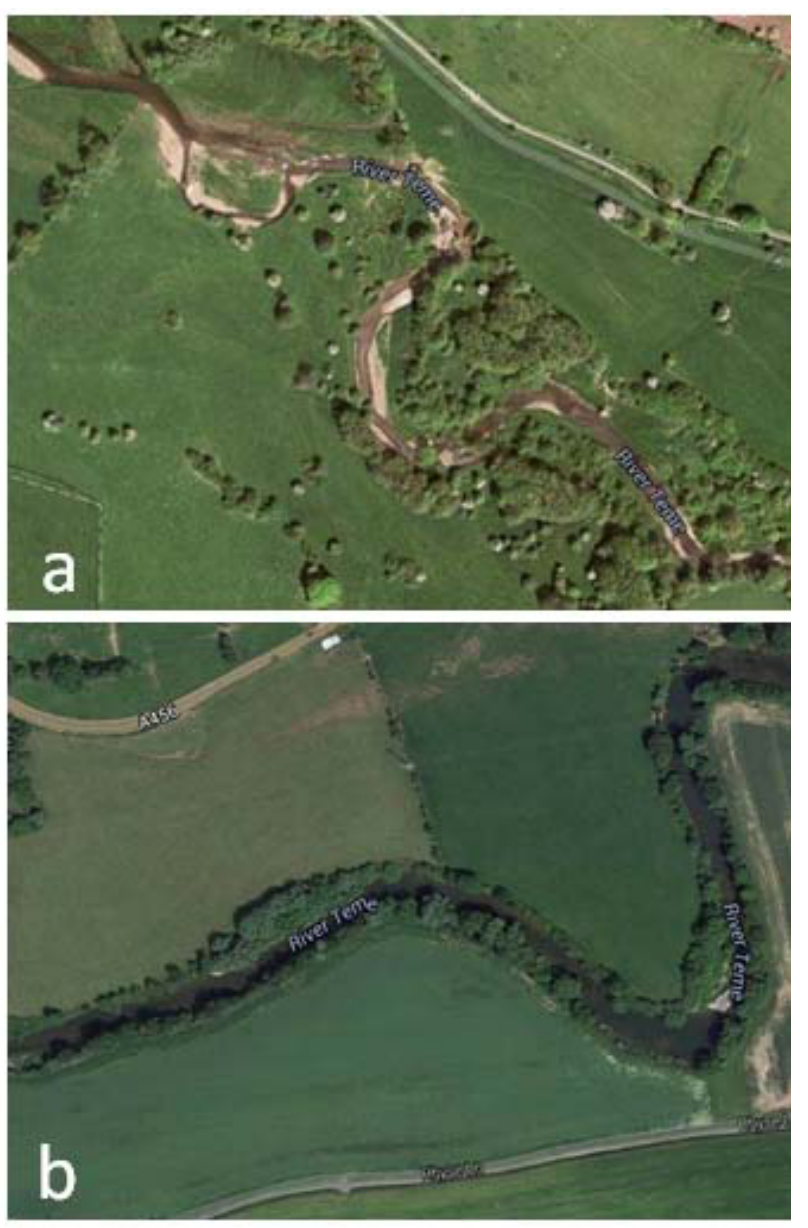

Figure 10. Very well connected wandering reach on the River Teme (a) and contrasting disconnected inactive single thread reach on the same river (b). 


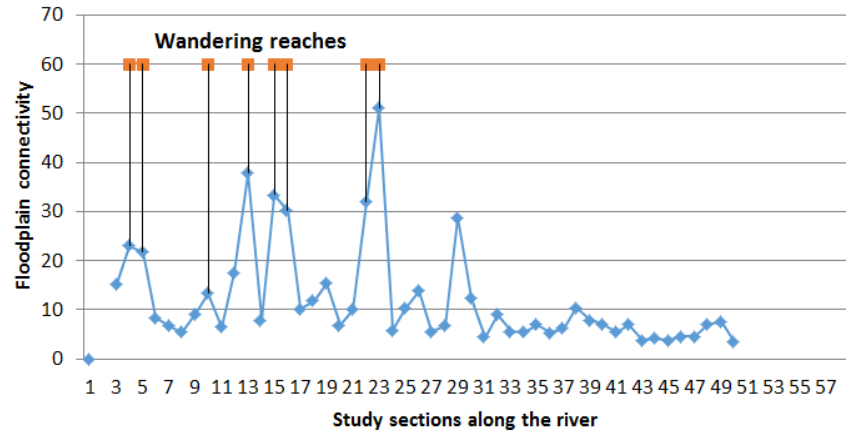

Figure 11. The association of wandering channel types with very well connected reaches on the River Teme.

\section{Discussion}

It is clear from the analysis of floodplain connectivity on the eight SSSI rivers in England and Wales that even these high value watercourses are significantly impacted by current and former engineering and management of the river and valley bottom. Table 2 revealed an intense use of the floodplain along all of the watercourses resulting in a loss of natural habitat to farming. Current and legacy engineering and management of the watercourses have also impacted on the hydrology, even where the watercourses were not embanked there was a high degree of disconnectivity most likely linked to direct dredging and indirect disruption to the bedload transport regime. Impacts on floodplain character and functionality will be significant. Thoms [1] noted this on the lower Balonne floodplain, Australia. Where the magnitude, frequency and duration of flooding events have all been reduced and levees and water storages has impacted the reactive floodplain surface area. The impact on floodplain hydrology is spatially variable along the study watercourses but where it is impacted the frequency of flooding has been significantly lowered. The resultant negative impact on floodplain function is significant as hydrology is by far the single most important driving variable in floodplains controlling as much as $60 \%$ of floodplain function [16]. This impact is best illustrated through the observed development of dynamic active single thread and wandering channel types along very well connected reaches of many of the SSSI study rivers.

The reduced flood frequency experienced along disconnected reaches will see a much reduced geomorphic dynamism. This will degrade the system as floodplains are disturbance-dominated ecosystems characterized by a high level of habitat heterogeneity. A reduced variety and lowered functionality of geomorphic units will impact on biotic diversity which has adapted to the high spatio-temporal heterogeneity.

The degradation to floodplain character and functionality revealed by this study of SSSI river systems across England and Wales suggest that a re-think is required regarding our approach to managing floodplains and funding floodplain restoration. Greater recognition of the natural role of the floodplain as a resource for upstream flood management and as an agent for overall biotic improvement is vital before these already highly degraded systems lose all of their functionality.

\section{References}

[1]. Tockner, K, Stanford JA, (2002) Review of: Riverine Flood Plains: Present State and Future Trends. Environmental Conservation 29: 308-330

[2]. Amoros, C. \& Roux, A. L. (1988): interaction between water bodies within the floodplains of large rivers: function and development of connectivity. münstersche geographische Arbeiten 29: 125-130.

[3]. Junk, W.J., Bayley, P.B. \& Sparks, R.E. (1989): The flood pulse concept in river floodplain Klimo, E. \& Hager, H., eds. (2001) The Floodplain Forests in Europe.

[4]. Thoms, M. C. (2003). Floodplain-river ecosystems: lateral connections and the implications of human interference, Geomorphology 56 (3), 335-349

[5]. Nanson, G. C., and J. C. Croke. "A genetic classification of floodplains."Geomorphology 4.6 (1992): 459-486.

[6]. Mitsch, W.J. \& Gosselink, J.G. (2000) Wetlands. New York, USA: Wiley.

[7]. Wenger, E. L., Zinke, A. \& Gutzweiler, K. A. (1990) Present situation of European floodplain forests. Forest Ecology and Management 33/34: 512.

[8]. Klimo, E., \& Hager, H. (Eds.). (2001). The Floodplain Forests in Europe: Current Situations and Perspectives (Vol. 10). Brill.

[9]. Dynesius, M. \& Nilsson, C. (1994): Fragmentation and flow regulation of river systems in the northern third of the world. - Science. 266: 753-762.

[10]. Schiemer, F. (1999): Conservation of biodiversity in floodplain rivers. - Archiv für Hydrobiologie, Supplement 115 Large Rivers 11: 423-438.

[11]. Fuller, I. C., Large, A.R.G., Heritage, G.L., Milan, D.J. and Charlton, M. E. (2005) Derivation of annual reach-scale sediment transfers in the River Coquet, Northumberland, UK., International Association of Fluvial Sedimentologists Special Publication, 35, 61-74.

[12]. Heritage G.L and Hetherington D, (2007) Towards a protocol for laser scanning in fluvial geomorphology, Earth Surface Processes and Landforms, 32 (1), 66-74

[13]. Bentley, S.G., England, J., Heritage, G., Reid, H., Mould, D. \& Bithell, C. (2016). Long-reach Biotope Mapping: Deriving Low Flow Hydraulic Habitat from Aerial Imagery, River Research and Applications, DOI: 10.1002/rra.3000

[14]. Rosgen, D.L. (1994). A Classification of Natural Rivers. Catena, 22: 169-199.

[15]. Lee, J. and Julien, P. (2006). Downstream Hydraulic Geometry of Alluvial Channels. Journal of Hydraulic Engineering, 132(12), 1347-1352.

Keddy, P.A. (2000) Wetland Ecology. Principles and Conservation. Cambridge, UK: Cambridge University Press. 